\title{
Implementing a Person's Right to Privacy When Using Their Biometric Material
}

\author{
Alsu Machmutovna Khurmatullina ${ }^{1}$, Evgeniy Batyrovich Sultanov ${ }^{1}$, Rimma Rashitovna Amirova ${ }^{1} \&$ Olga \\ Mikhailovna Smirnova $^{2}$ \\ ${ }^{1}$ Department of Constitutional and Administrative Law, Kazan Federal University, Kazan, Russia \\ ${ }^{2}$ Department of Biomedical Ethics, Medical Law and History of Medicine, Kazan State Medical University, \\ Russia \\ Correspondence: Alsu Machmutovna Khurmatullina, Kazan Federal University, Russia. E-mail: \\ akm551@mail.ru
}

Received: June 9, 2019

Accepted: August 25, 2019 Online Published: August 31, 2019

doi:10.5539/jpl.v12n5p38

URL: https://doi.org/10.5539/jpl.v12n5p38

\begin{abstract}
The significance of regulating people's personal data in the context of implementing each person's right to privacy of personal life and family life becomes especially crucial for the purposes of ensuring biogenetical safety of people in Russia. This requires raising the issue of implementing the right to privacy in the context of the biotechnological revolution. The special legal significance of this issue in the Russian Federation is connected with the passing of such laws as the Law "On personal data" and the Law "On state genome registration in the Russian Federation".

This article analyzes the legal status of biometric personal data. We note the need for legal regulation of the protection of biometric information as confidential data.

The results of this research are based on using the following methods: universal dialectical method of scientific cognition, as well as general scientific methods based on it (description, analysis, synthesis, induction, deduction, comparison, analogy, generalization) and specific scientific methods (comparative law method, systematic structural method and formal law method).
\end{abstract}

Keywords: privacy, right to privacy, confidentiality, personal data, biometric personal data, legal regulation

\section{Introduction}

The modern world treats the right to privacy as one of the basic personal citizen's rights of each person.

In 1948, the Universal Declaration of Human Rights was passed: its Article 12 declares the privacy of personal life. Later on, this rights was established by other law: The International Covenant on Civil and Political Rights (Article 17), the European Convention on Human Rights (Article 8), American Convention on Human Rights (Article 11), Convention of the Commonwealth of Independent States on Human Rights and Basic Freedoms (Article 9).

Various areas of a person's life - family, household, religion, recreation, communication - are a matter of personal life subject to privacy. It always includes things that are strictly private for a person. Despite the fact that the claim for privacy in universal, its concrete form differs according to the prevailing societal characteristics, the economic and cultural environment.

A whole new level of understanding of this right and the limits of its implementation became relevant in early XXI century, with the advent of a new technological reality into the society. Realizing the scale of new threats, the UN Human Rights Council in July 2015 formed a new Institute of Special Rapporteur on the issue of privacy.

"The right to privacy in the digital age" (A/HRC/27/37) - that was the name of the report of the United Nations High Commissioner for Human Rights that was presented at the working meeting of experts that was held in Geneva in February 2018.

\section{Methods}

The comparative law analysis method helped identify the distinctive features of biometric personal data. 
The use of the systematic structural method of cognition allowed the authors to make a conclusion regarding the need for strict legal protections for human genetic data to ensure the implementation of the right to privacy.

The formal law method of research was used to determine the content of such terms as "privacy", "personal data", and "biometric personal data".

\section{Results}

One of the media that carries human genetic data is a person's germ cells. The are used in assisted reproductive technologies (ART), state genome registration/identification, genetic testing / genetic diagnostics, and in gene therapy.

In accordance with Federal Law No. 323 "On the basics of healthcare of citizens in the Russian Federation" (Article 55), anyone may use assisted reproductive technologies to treat infertility, as well as anyone willing to donate germ cells for infertile couples or single women.

Even though internal legislation regulates the process of using the ART, their contraindications and limitations of use, it does not regulate the maximum permitted storage period of germ cells (even though it is limited from the biological perspective), and also does not limit the extraction of information contained in the DNA of the donor.

The DNA information thus obtained is only protected by the medical confidentiality, but since the information contained in the DNA constitutes biometric personal data, it should be protected in a stricter way, which is not yet required by the above regulations.

\section{Discussion}

The privacy is defined as the "presumption that private individuals should have a certain space for independent development, interaction and freedom, a private area for interacting with other people or without interacting with them, and that space should be free from the interference by the state and excessive interference by other unwelcome private individuals".

The Russian Constitution of 1993 guarantees the right to privacy of each person in Chapter 2, "Rights and freedoms of human and citizen". Part 1, Article 23 states that "each has the right to privacy of personal life, personal secrecy and family secrecy", and Part 1, Article 24 establishes a limitation on the "collection, storage, use and dissemination of information about an individual's private life without their consent".

Russian law does not have a legal definition of the notion of private life, but the right to privacy of private life is established by constitutional law and other law in the Russian Federation.

Note: the expression "private life" is often used as a synonym to "personal life".

Russia's need to respond to threats created by the digital world and the biotechnological revolution in the context of the right to privacy has special legal significance due to the passing of Law No. 152-FZ "On personal data" dated 27 July 2006, and Law "On state genome registration in the Russian Federation" dated 3 December 2008 No. 242-FZ .

The Federal Law "On personal data" regulates the processing of personal data, dissemination, provision, blocking, destruction, anonymization and cross-border transfer of personal data by federal authorities, regional authorities, local authorities, legal entities and individuals using automated tools, including telecommunication networks (the law does not apply to the processing of personal data by individuals solely for personal and family needs, if this does not violate the rights of the subjects of personal data).

For the purposes of that law, personal data is understood to be "any information that is related to an immediately identifiable or indirectly identifiable individual (the subject of personal data)".

Article 11 separately regulates biometric personal data, which are understood as "information that characterizes physiological and biological features of a person that can be used to identify them (biometric personal data) and that are used by the processor to identify the subject of personal data". Biometric identification or authentication has traditionally been based on human processes: a person comparing characteristics of an individual to those characteristics of individuals that have been otherwise obtained. At the same time, we should bear in mind that identification and identity management are not synonymous with biometrics, which is simply one instrument among many for identifying and authenticating individuals.

This type of data can be processed only with a written consent of the subject.

For safety purposes, to counteract terrorism and corruption, and for the purposes of law enforcement and justice, the law permits processing of biometric personal data without the consent of the subject. 
Due to new scientific discoveries, the methods of human identification keep improving. Today, genetic-based methods of identification become one of the most highly-demanded methods. Besides healthcare and medicine, there is a number of practical applications in other spheres of life. "Once the individual re-presents the biometric information, the unique PIN or key is recreated and compared with the string that has been stored. Essentially, the biometrics may be seen as a decoder of the unique PIN, allowing the individual to be authenticated".

It should be noted that human germ cells may be used as biometric genetic data and as the material for the purpose of State genome registration (SGR), which is regulated by Federal Law "On state genome registration in the Russian Federation" and Federal Law "On information, information technology and protection of information".

The purpose of SGR is to identify a person. Types:

- voluntary SGR (can be used by Russian citizens, foreigners and stateless persons residing or temporarily staying in Russia);

- involuntary SGR (applies to persons convicted or serving a sentence for serious and extremely serious crimes, as well as all types of sexual offences).

Notably, the legislation permits the Ministry of Internal Affairs of Russia to create a federal database of genome information. In this case, proper protection of genetic information is ensured by Federal Law No. 149 "On information, information technology and protection of information" and Federal Law No. 52 "On personal data".

Unfortunately, the legislation does not establish a strict access system for persons authorized to access the genetic information when performing the above SGR procedures.

Genetic testing may also be performed based on the genetic data in human germ cells. This medical procedure recently became especially popular, since each one of us is interesting in finding out predispositions to diseases and one's biological nature in general.

This procedure is vulnerable from the point of view of preserving the privacy of personal information obtained during the testing process, since there are no detailed regulations for such procedures and the subsequent circulation of such genetic information.

As a result of such testing, the patient receives information concerning, for example, predisposition for a certain disease, but at the same time this information constitutes information about his ancestors, living family members and subsequent generations (children and grandchildren); thus it turns out that in this situation, receiving a patient's written consent for the processing of personal information only is not sufficient.

Conclusion. Legislators, together with genetics experts and doctors, are yet to figure out the legal mechanism for implementing privacy in genetic testing.

Russian authorities are already taking steps to control and regulate the handling of human biomaterials in the interest of state security, which is evidenced by the Order No. 917 issued on 11 February 2019 by the Federal Healthcare Supervision Service "On approving the Administrative Regulations of the Federal Healthcare Supervision Service for providing the public service of issuing approvals for licenses to import into the Russian Federation and export from the Russian Federation human organs and tissues, blood and its components (except samples of human biological materials, haematopoietic stem cells, bone marrow, donor lymphocytes for the purposes of sibling transplant, germ cells and embryos)".

In the near future, Russian authorities plan to create a genetic passport of the Russian citizen by collecting the data "about the individual human genome and creating a genetic profile of the population". This should help protect Russians against biological and chemical threats.

\section{Conclusions}

1) Russian law currently underestimates the importance of genetic information which can be extracted from human biological material and constitutes human biometric data.

Legislation lacks boundaries for deciphering the genome information during such procedure. Meanwhile, in foreign literature, Marian A. Waldmann Agarwal and Adam J. Fleisher note that "Legislation taking shape varies but has tended to follow one of two possible approaches: (1) a risk-based approach that limits protections to some subset of biometric information generally based on whether it can be used to uniquely identify or authenticate an individual; or (2) adding to or interpreting the definition of personal or sensitive personal information to include biometric information resulting in biometric information being covered by existing data protection laws".

2) On the legislative level, there is a lack of a reliable system for protecting and storing genetic information obtained as a result of medical procedures. 
Given the above, we believe that existing Russian laws should be used to grant special status to genetic information.

A special role in that must be played by civic institutions (National Medical Chamber of the Russian Federation) and by the Ministry of Healthcare of the Russian Federation, since "their operations must be aimed at implementing or assisting in implementing existing rights and freedoms of persons and citizens".

\section{Acknowledgments}

The work is performed according to the Russian Government Program of Competitive Growth of Kazan Federal University.

\section{References}

Amirova, R. R. (2011). Forms of protection of rights and freedoms of a person and citizen. Science in Tatarstan, Kazan: Academy of Sciences of the Republic of Tatarstan Publishing House.

Backman, P., \& Kennedy, C. (n.d.). Biometric Identification and Privacy Concerns: A Canadian Perspective. Retrieved from https://www.airdberlis.com/docs/default-source/articles/biometric-identification-and-privacy-concerns.pdf?s fvrsn=2

Cavoukian, A., \& Snijder, M. (2009). A Discussion of Biometrics for Authentication Purposes: The Relevance of Untraceable Biometrics and Biometric Encryption. Information and Privacy Commissioner of Ontario. Retrieved from http://www.ipc.on.ca/images/Resources/untraceable-be.pdf

Constitution of the Russian Federation. Passed by popular vote on 12 December 1993. Retrieved from http://http://www.consultant.ru/document/consdocLAW28399/

Gelb, A., \& Center, J. C. (n.d.). Identification for Development: The Biometrics Revolution. CGD Working Paper 315. Washington, DC: Center for Global Development. Retrieved from http://www.cgdev.org/content/publications/detail/1426862

Majtényi, L. (2006). Az információs szabadságok: adatvédelem és a közérdekü adatok nyilvánossága. Complex, Budapest.

Marian, A., Agarwal, W., \& Fleisher, A. J. (2019). Biometric Information as Personal Information - A Brave New World of Regulatory Compliance. Morrison \& Foerster LLP. Retrieved from https://www.mofo.com/resources/publications/170404-biometric-information-personal.html\#_ftnref1

Report of the UN High Commissioner for Human Rights. UN official website. Retrieved from https://undocs.org/ru/A/HRC/39/29

\section{Copyrights}

Copyright for this article is retained by the author(s), with first publication rights granted to the journal.

This is an open-access article distributed under the terms and conditions of the Creative Commons Attribution license (http://creativecommons.org/licenses/by/4.0/). 